Volume and Issues Obtainable at Center for Sustainability Research and Consultancy
Sustainable Business and Society in Emerging Economies
ISSN: $2708-2172$ \& (E): 2708-2504
Volume 3: Issue 4 December 2021

\title{
Pressure Groups and Free Press: Downsizing in News Organizations and Future of Traditional Media in Pakistan
}

*Jam Sajjad Hussain, Directorate of Outreach, Communications and Public Relations, Directorate of Career Counselling and Placement Center, The Islamia University of Bahawalpur- Punjab, Pakistan Ghulam Shabir, Professor, Faculty of Media and Communication Studies, University of the Central Punjab, Lahore, Pakistan

Nasir Hameed, Director Public Relations, Bahawalpur Division, Bahawalpur, Government of the Punjab, Pakistan

Shahid Afzal Durrani, Director Career Counselling and Placement Center, The Islamia University of Bahawalpur- Punjab, Pakistan

*Correspondent Author's Email: jamsajjadhussain@gmail.com

\begin{tabular}{l}
\hline ARTICLE DETAILS \\
\hline History \\
Revised format: Nov 2021 \\
Available Online: Dec 2021 \\
\hline Keywords \\
Developing Countries, \\
Freedom of Speech, Job \\
Satisfaction, News Channels, \\
Qualitative Approach \\
\hline
\end{tabular}

JEL Classification

L80, L82

\section{OPEN ACCESS}

\section{ABSTRACT}

Purpose: News media in third world countries remained under social, religious, political and military pressure. Developing countries in presence of pressure groups cannot enjoy the fruits of a democratic setup. So, the purpose of study is to explore factors of downsizing in traditional media organizations and their future in wake of pressure groups, which create hindrance in freedom of expression.

Design/ Methodology/ Approach: Qualitative approach was employed to explore the causes behind the undesired downsizing. Researchers chosen 15 respondents working on senior positions in different traditional media organization from different stations of Pakistan including Islamabad, Lahore, Multan, Bahawalpur and Karachi based on purposive sampling.

Findings: Results revealed the incumbent government changed its stance on freedom of expression and adopted each modus operandi to silence the voices from journalistic corners. The government promoted selective part of freedom of expression by highlighting the anchors speaking in favor of the party.

Implications/ Originality/ Value: So, the study concluded traditional media organizations should be reorganized and government should extend its democratic support for protecting freedom of expression. The study recommended the government should remain impartial and provide space to traditional news organizations so that the citizens should be provided with right to know.

(C) 2021 The authors, under a Creative Commons AttributionNonCommercial- 4.0

Recommended citation: Hussain, J. S., Shabir, G., Hameed, N. and Durrani, S. A. (2021). Pressure Groups and Free Press: Downsizing in News Organizations and Future of Traditional Media in Pakistan. Sustainable Business and Society in Emerging Economies, 3 (4), 545-555. 


\section{Introduction}

The right to information and freedom of speech has been enshrined in the Constitution of Pakistan in the footprints of other countries across the globe where democratic setups are governing the state's structure with having media access (Acemoglu \& Robinson, 2020; Price, 2002). Freedom of speech, as explained in the First Amendment, is the fundamental right of an individual to express thoughts, opinion and influence other members of the society in the USA (Baker, 1977). However, there are multiple states on the map of the world which have prohibited functionality of free press (Steiniger \& Hunter, 2013) but they have subjected the media to function in accordance with the directions of the ruling class (Hartley, 2019; Robinson \& Robinson, 2004). Media cannot report, publish or air news stories or spread any piece of information without prior approval of the state's authorities (Herman \& Chomsky, 2010). Such states are governed by the monarchs, kings, powerful presidents, chairmen etc., who enjoy absolute powers on systems of parliament, judiciary, army, media and other bodies of the country (Sultana, 2012; Suwannathat-Pian, 2013). The critics of such states believe the ruling class in such states cannot allow free press to challenge their authorities, therefore, they have firm grip on the veins of mass media (Humphreys, 1996; Ogundiya, 2010). In Saudi Arabia, Jordan, North Korea, Russia, China, Iran and other such countries, mass media is the powerful mouthpiece of the ruling authorities (Bell, 2018) to provide only that message which assists the ruling class in strengthening their powerful grip on the system (Boserup, Woertz, Hassan, Nagyné Rózsa, \& Zaccara, 2019; Heydarian, 2020). In such situation, the rights like the freedom of press or right to information are crushed by these states thus infringing the fundamental right of the individual(s) (Ho, 2007; Roberts, 2001). The people in power corridors in such states, however, consider 'free press' a misconception as they believe media is the body which assists government 's operations (Graber \& Dunaway, 2017) instead of questioning their actions for 'public welfare'. On the other side, critics sheltered by the ruling class in such states criticize the freedom of press in other countries mostly governed by the democratic setups. According to the critics, free press is threat to state's authority (Bollinger, 1994) therefore it should work in accordance with the lines and directions of the government(s). However, democracy believes in safeguarding the fundamental rights of citizens and further protect their basic rights as envisaged by the constitutional jurisdictions (Von Bogdandy, Kottmann, Antpohler, \& Dickschen, 2012). According to them, there is a long list of famous world leaders, who endowed their life for provision of basic rights to citizens of their countries while stressing upon the need of freedom of press. Martin Luther King Jr. wanted a free press which may work rather may guide the state's machinery for steps and actions for wellbeing of the citizens of the United States of America (Dyson \& Jagerman, 2000). Muhammad Ali Jinnah, the Founding Father of Pakistan, himself was in favor of free press which may assist the struggle of Pakistan Movement. Mr. Jinnah himself founded a Daily Newspaper - Dawn - and directed Majid Nizami, Founder of Daily Nawaiwaqt - an Urdu newspaper to guide the leadership of Muslim League besides criticizing the state's machinery, once in power, so that state could identify its deficiencies and streamline its functions (Hali, 2010; Kalia, 2012).

If we analyze the circumstances of Pakistan, the media was working without any limits despite having regulatory law of Pakistan Electronic Media Regulatory Authority during previous governments including retired General Pervez Musharraf, Pakistan Muslim League (Q), Pakistan Peoples' Party, Pakistan Muslim League (N) and before arrival of the government led by Pakistan Tehreek-e-Insaf. The PTI-led government has almost restricted the free press while imposing ban on advertisements (Shahbaz, 2020). Government's advertisements are the lifeline of the traditional media organizations but once these advertisements are restricted the entire traditional media organizations i.e., print media and electronic media organizations starts shaking. The incumbent government through Press Information Department (PID) and Directorate General of Public Relations (DGPR) both have withheld the advertisements, resultantly, the news organizations have started downsizing. Hundreds of thousands of employees ranging from news reporters, sub-editors, page makers, run down editors, city editors, district reporters, news editors, anchors and even news editors have been fired from their jobs on the pretext of financial constraints (Kapoor, 2016; Pickering, 2017). According to the observation during the last two years, the researchers tried to unearth the true reasons for which such circumstances have prevailed and 
continuous threats are looming the heads of mainstream traditional news organizations.

\section{Arguments of Social Scientists and Scholars}

Grant (1989) believed pressure groups always have tangible impact on the working of traditional media organizations in any part of the world. Klausen (2005) maintained that different pressure groups including political parties, religious groups, seminaries, terrorist organizations, banned outfits, government functionaries, bureaucratic circles as well as other pressure groups control the freedom of press. Booth, Aivazian, Demirguc-Kunt, and Maksimovic (2001) stated these pressure groups are always powerful in all countries with slight difference of ratio in developed as well as developing countries. According to Frum and Perle (2004), the intelligence agencies have firm grip on traditional media organizations in America, United Kingdom, France, Germany, Holland, Israel, North Korea, etc., with minor difference of projection of news stories. According to a study, intelligence agencies do not want free press as the stakeholders believe such 'freedom of press' poses threat to solidarity of the country. Plunkett (2003) believed monarchs and kings never accept free press, as such sort of freedom of press challenges the life of their monarchy besides their control on the life of the country. Therefore, according to Sakr (2013), kings and dictators including Saudi Arabia and Egypt respectively cannot let the press operate freely, but they want the mass media to act as their mouthpiece. According to Billig (2002), not a single news organization can publish any story against the life, financial setups, and other affairs of the royal family including Queen of England. If this is the situation of the UK, which generally advocates provision of civil rights, free press, freedom of speech etc., etc., then how can one expect free press operating in any democratic or dictatorial state?

According to Davies (2011), even no traditional news organization or news reporter can file, carry, publish or air news against the powerful intelligence agencies including Central Investigating Agency (CIA), National Security Agency or other dozens of such intel organizations working in the United States of America (Downie Jr \& Kaiser, 2007). Julian Assange, a journalist facing trials on charge of freedom of speech, is the classical example of freedom of speech (Steel, 2013). The study concludes that from this particular Assange, which developed country can deviate from the harsh reality that the concept of free press in the western countries is not less than a myth.

According to Woertz (2019), Jamal Khashoggi, a journalist hailing from Saudi Arabia, was skinned to death in Saudi Embassy in Turkey on the orders of a powerful ruling figure from the royal family but what happened to the wrongdoers. Nothing. The same is the case of North Korea, Russian and other such states where freedom of speech or free press is a fairy tale. Gunther and Diamond (2003) stated that no country allows any news against the powerful ruling class, bureaucracy, orthodox religious organization or the powerful political parties. According to a study, in continuation of such practices across the world, the incumbent ruling party - PTI - has imposed ban on advertisement just to seek mileage and guillotine the freedom of press in Pakistan. The above-said findings of various studies and eye opening documentary evidences were found sufficient to proceed for the research underhand with aims to explore the reasons which are causing hindrance in freedom of press in Pakistan.

\section{Press at Liberty}

The famous scholars including Milton, Locke, and Mills have argued that it was the duty of the mass media to inform, entertain, sell and even help the government's machinery in unearthing truth about social, economic, political and other mechanisms of the state (Bennett \& Raab, 2017). According to the social scientists and scholars of mass media, Libertarian Theory was the most appropriate theoretical foundational arena in which mass media can operate with liberty and performs its functions (Christians, Glasser, McQuail, Nordenstreng, \& White, 2010). The theory suggested there must be minimal checks and balances proposed by the government for media, however, the traditional [mass] media should also abide by the social norms and avoid defaming and show obscenity. This theory altogether objected or even negated the authoritarian theory while providing libertarian approach to mass media in democratic setups. Scholars believed the basic philosophy behind this theory was considering people wise persons 
who can perfectly distinguish between truth and false, therefore, traditional mass media should play its objective role by showing the reality with liberty. Basically, this theory proposed the [mass] media should enjoy the complete autonomy in content airing/ publishing and it can even attack the government's policies, journalists also enjoy absolute freedom within the traditional media organizations, the [news] media must be free from any sort of censorship and there should be no relationship between media and the government. Overall, libertarian approach objected the authority of the authoritarian theory and advocated for free press without any regulation by the government (Akhavan-Majid \& Wolf, 1991; Boaz, 2010) subject to certain suggestive measures of avoiding showing obscenity or infringing fundamental rights of the individual(s) of the society. In fact, early libertarians believed that if the people freed from the restricted and imposing information of churches and the limitations of state, would adjust themselves and others with the free press advocating for their fundamentals rights (Rabban, 1985; Smith, 1990). Accordingly, this approach seemed appropriate for the circumstances of mass media prevailing in Pakistan where the culture of downsizing has reached to alarming level owing to government's initiatives of stopping advertisements for traditional media organizations during the incumbent government led by the Pakistan Tehreek-e-Insaf (PTI) with Imran Khan as its Prime Minister.

\section{Research Objectives}

In order to measures opinion of the respondents, the researchers designed following objectives for the study in hand:

RO1: To analyze the existing circumstances of traditional media functioning in Pakistan

R02: To describe factors endangering freedom of speech of traditional media organizations

Research Hypothesis

$\mathrm{H} 1$ : It is likely to assume that the functioning of traditional media organizations is directly linked with government's advertisements

$\mathrm{H} 2$ : It is likely to assume that traditional media organizations are under financial crisis due to PTI-led government's measures to curb freedom of speech

H3: It is likely to assume government's advertisements financial cut leads to curbing freedom of speech in traditional media organizations in Pakistan

\section{Materials and Methods}

The study in hand is an effort to gauge the opinion of the newsmen i.e., editors, reporters, sub-editors, layout editors, page makers, and other support staff working in traditional media organizations in Pakistan. The researchers intended to collect first-hand information from the respondents directly involved or affected by the hypothetically assumed propositions about the factors endangering freedom of speech. The most appropriate methodology for the research in hand was chosen qualitative approach to collect appropriate responses as quantitative methodology seemed quite difficult for this general phenomenon because the panorama of curbing freedom of speech was general in nature and it seemed difficult to collect information of all the employees associated with different formats of media industry in Pakistan. Almost all the news channels and workers associated with these traditional media organizations were complaining that government's measures were creating hindrance in freedom of speech, therefore, the researchers employed qualitative method to collect data from top management of the traditional organizations.

Accordingly, all the traditional media organizations functioning in Pakistan were considered the population and all the workers employed by these traditional news organizations were taken as a sample frame, whereas the researchers chosen 15 newsmen as respondents, virtually sample size, of the study. The researchers earlier planned to involve maximum respondents but it seemed quite tough owing to prevailing pandemic of COVID-19. A structured questionnaire with 15 open ended items/ questions was distributed online among the respondents followed by a detailed telephonic call to collect the qualitative data. 


\section{Thematic Analysis}

The researchers employed thematic analysis technique to examine the opinion of the respondents. A detailed coding sheet was developed carrying categories, different themes, codes and their description were incorporated in the coding sheet.

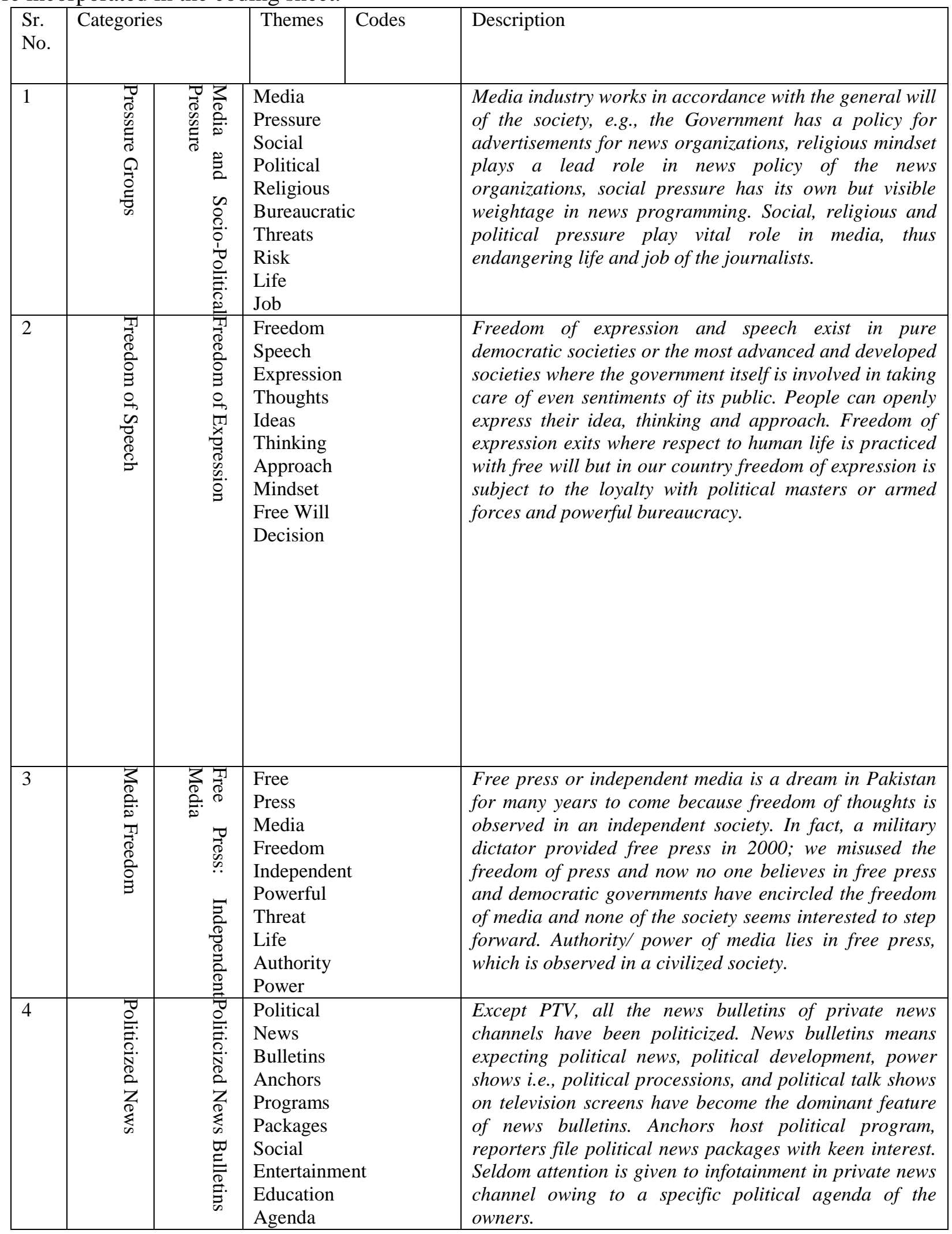




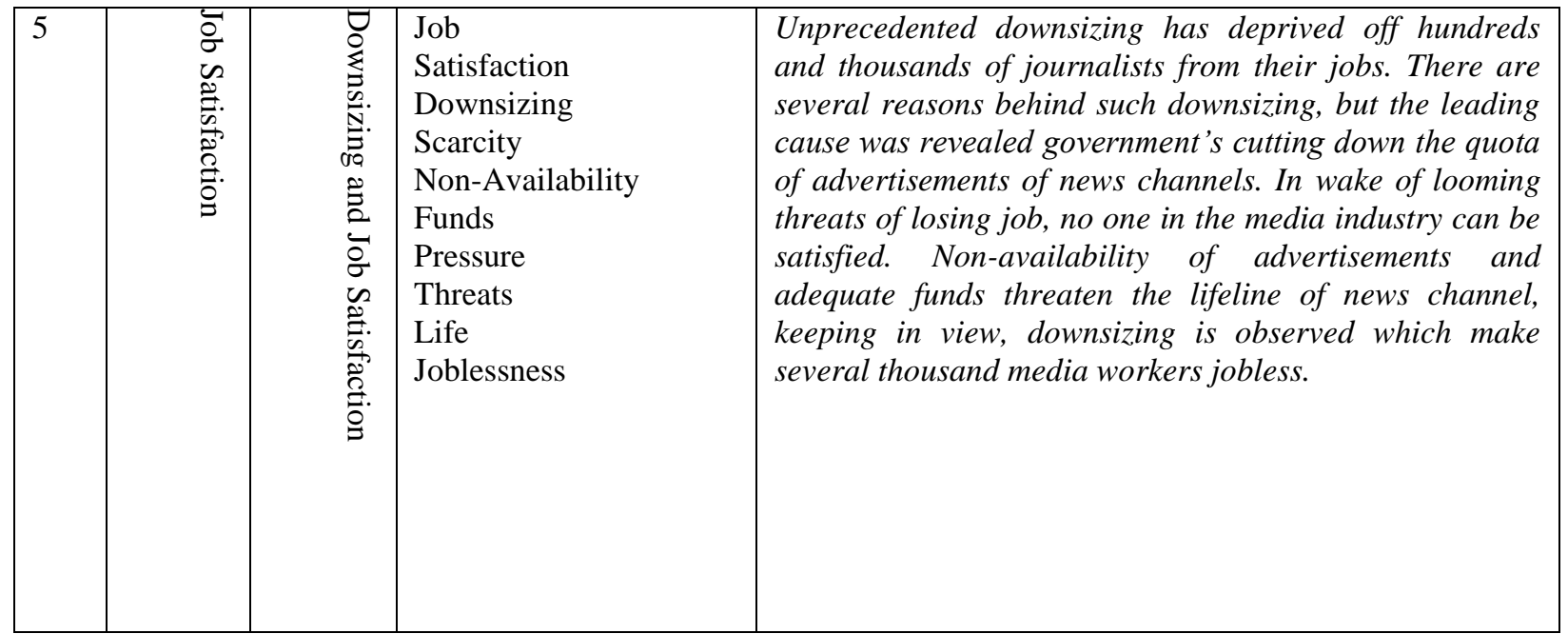

\section{Respondents of the Study}

As discussed above, the researchers selected 15 respondents working as middle management in news channels. The respondents fell in line of deputy bureau chiefs, bureau chiefs and controller news, however, keeping in view the nature of questionnaire, almost all the respondents requested to keep them anonymous otherwise they may lose the job once they openly spoke about the social pressure, pressure groups and government's pressure on the owners of the news channels. Due to nature of the research questions and sensitivity of the matter under discussion, the researchers employed purposive sampling to collect desired data within stipulated timeframe. However, the researchers included the table of the respondents in following order, while making effort to conceal their identity.

\begin{tabular}{llll}
\hline Name & News Channel & Office & Station \\
\hline XYZ & Geo News & Bureau Office & Lahore \\
XYZ & Express News & Bureau Office & Lahore \\
XYZ & Aaj News & Bureau Office & Lahore \\
XYZ & PTV News & Regional Office & Lahore \\
XYZ & Dunya News & Bureau Office & Karachi \\
XYZ & 24 News & Head Office & Lahore \\
XYZ & PTV News & Head Office & Islamabad \\
XYZ & Geo News & Head Office & Karachi \\
XYZ & Dunya News & Bureau Office & Multan \\
XYZ & PBC & Head Office & Islamabad \\
XYZ & News One & Bureau Office & Karachi \\
XYZ & PNN & Head Office & Lahore \\
ARY News & Bureau Office & Lahore \\
BYZ & Aaj News & Bureau Office & Multan \\
XYZ & Roohi News & Head Office & \\
XYZ & & & \\
\hline Total 15 & & & \\
\hline
\end{tabular}


Source: Fictitious names of respondents, for illustration purposes only

\section{Themes of the Study}

Based on the patterns of the data, the researchers developed five main themes from the qualitative data, which are given as: -

Media and Socio-Political Pressure

Freedom of Expression

Free Press: Independent Media

Politicized News Bulletins

Downsizing and Job Satisfaction

Data Analysis Technique

After detailed deliberations with the experts of qualitative data in Pakistan, especially in the field of media and communication, the researchers selected one of the most suitable and appropriate responses of the respondent(s) and elaborated in detail to discuss the overall theme in larger perspective.

\section{Results}

The researchers developed five categories, derived five main themes, developed codes and described them in the light of data collected from the respondents.

\section{Theme No. 1}

\section{Media and Socio-Political Pressure}

According to a respondent, who has worked with multiple mainstream news organization including newspapers and news channels for the last 17 years in Lahore,

"Media industry works in accordance with the general will of the society, for instance, the Government has a policy for advertisements for news organizations, religious mindset plays a lead role in news policy of the news organizations, social pressure has its own but visible weightage in news programming".

Interpretation of Theme: - Most of the respondents responded almost in the same way as the main quote has been shared about media and social pressure. According to the theme, 'press at liberty' has become a concept of past in Pakistan because every democratic government was blocking the ways of freedom of press. Media industry comprised on two main sectors - print media and electronic media - was first in the hands of businessmen, who have established contacts with political powers, bureaucracy, religious parties and other landowners. First media organizations were run by the journalists accordingly they had a sense of news, but these days, media industry has become a business. Therefore, the traditional media organizations take pressure from any corner which provides business to the organization. In fact, now news organizations themselves have devised a red-line keeping in mind the vested interest of their owners. Now, news, editorial, and program policy is devised by the owner, not by the news editors.

\section{Theme No. 2}

\section{Freedom of Expression}

"Freedom of expression exists in pure democratic societies or the most advanced and developed societies where the government itself is involved in taking care of even sentiments of its public. Freedom of expression exits where respect to human life is practiced, but in our country freedom of expression is subject to the loyalty with political masters or armed forces and powerful bureaucracy," commented a respondent who has been working as a controller news in Islamabad for the last 20 years.

Interpretation of Theme: - Freedom of expression is the backbone for an independent or free press. The journalists in Pakistan and abroad have sacrificed their lives and lost jobs, suffered economic consequences just because of freedom of express. The abovementioned theme carries multiple factors related to freedom of expression. It is an independent approach of any citizen to express his/ her feelings without any threat to life or job. It is the custom of a civilized society where democratic will prevails with full spirit. The respondents [who are the journalists with more than 15-20 years of journalistic experience] believe we [our countrymen] lack respect to human life, therefore, in such circumstances, 
respect to freedom of expression is like dreaming without any surety of destination. During detailed deliberations, the respondents believed first we need to develop respect to human life, we need to respect to animal life, we need to respect to feelings of others, first we need to transform into a civilized society, then we can expect absolute freedom of expression not only from the journalists but also from our fellow countrymen. Freedom of expression is a concept which is observed among multiple family groups, friends' circles, political opponents, news anchors, reporters and others fabric of society. In prevailing circumstances, news organizations of Pakistan are under iron clutches of political masters, powerful army, bureaucracy and others social circles, therefore, one cannot observe, practice or openly express his/ her thoughts about ideas, religious, political affairs, foreign relations etc.

\section{Theme No. 3}

\section{Free Press: Independent Media}

According to a bureau chief of a national news channel in Multan,

"Free Press or Independent Media is a dream in Pakistan for many years to come. In fact, a military dictator provided free press in 2000; we misused the freedom of press and now no one believes in free press and democratic governments have encircled the freedom of media and none of the society seems interested to step forward".

Interpretation of Theme: - Absolutely, it is an established fact, that free press was a dream before 2000. Retired General Musharraf launched private media in Pakistan in 2000 and promulgated an Ordinance a well to monitor the media. However, the general himself indulged in self-praise and the anchors launched by him started praising his government. There was no punishment on violation of the PEMRA Ordinance, not a single license of any television channel was cancelled during military regime for which electronic media as well as print media became out of control. Media became a sacred cow afterwards and the worst misuse of free press was observed during and after the general Musharraf era. The concept of free press was misused to the extent that no one from other news channel used to even recheck the news when it was aired on Geo News, regardless the same news was proved fake. For instance, bomb hoax became a psychological threat for the families whose kids were in schools and such news used to air in red colored tickers flashed on television screens in recent past. Free press is an important concept but subject to certain social responsibilities compulsory for the news organizations.

\section{Theme No. 4}

\section{Politicized News Bulletins}

According to a news controller affiliated with a state-own television channel in Karachi for the last several years,

"Except PTV, all the news bulletins of private news channels have been politicized. News bulletins means expecting political news, political development, power shows i.e., political processions, and political talk shows on television screens have become the dominant feature of news bulletins".

Interpretation of Theme: - Pakistan Television commonly known as PTV is a state-run television since its inception in 1964 during a military rule of retired general Ayyub Khan. PTV has no fear of losing advertisements, therefore, it goes with the flow of the government's direction. However, PTV is the television of the state, therefore, the entire news, editorial or the program policy of the state is followed in true letter and spirit. The news bulletins of the PTV cannot be labelled as politicized because it airs entertainment programs for old, women and children, special programs for awareness are aired and the major portion of the bulletins also carries news for public awareness. However, private news channels are packed with political news, carrying political developments, PDM - Pakistan Democratic Movement - engagements, movement of heads of political parties, political talk shows and political engagements are the common and dominant features of the news bulletins on all private news channels in Pakistan.

\section{Theme No. 5}

\section{Downsizing and Job Satisfaction}

"Unprecedented downsizing has deprived off hundreds and thousands of journalists from their jobs. There are several reasons behind such downsizing, but the leading cause was revealed government's 
cutting down the quota of advertisements of news channels. In wake of looming threats of losing job, no one in the media industry can be satisfied," commented a senior bureau chief, who worked as a news editor in a newspaper and now he has been working with a national news channel in Lahore for the last several years.

Interpretation of Theme: - Downsizing is a common phenomenon in traditional news organizations, and the episode is repeated after a few years. However, during the last three and half years, the massive downsizing has been observed in all the news channels in Pakistan, consequently, thousands of media workers were deprived off from their jobs. Some of the news workers even committed suicide, some shifted to other professions, and some continued with the old jobs with new low salaries. Dawn News is believed to be the most professional new organization but it also imposed 40 percent cut on the salary of its workers during the incumbent PTI-led federal government. In wake of unprecedented downsizing, job satisfaction is merely a concept to make mockery otherwise one [media worker] cannot be satisfied with tall claims but with empty pockets. Traditional media organizations are quite powerful therefore they block the path of the government to enforce wage board awards providing perks and privileges to the media workers.

\section{Answers to Research Objectives and Hypothesis Testing}

Researchers have designed two research objectives, 1) To analyze the existing circumstances of news channels functioning in Pakistan, and 2) To describe factors endangering freedom of speech of news channels in Pakistan. Results revealed that the existing circumstances of the news channels were in deteriorating condition because of the government's advertisement policy. Furthermore, there are multiple factors including social, religious, political and bureaucratic pressure which were endangering freedom of speech. Likewise, three hypotheses were framed including 1) It is likely to assume that the functioning of news channels is directly linked with government's advertisements, 2) It is likely to assume that news channels are under financial crisis due to PTI-led government's measures to curb freedom of speech, and 3) It is likely to assume government's advertisements financial cut leads to curbing freedom of speech of news channels in Pakistan. According to the results, all three hypotheses were proved, as the data revealed the news channels have strong linkage with the flow of government's advertisements, however, the PTI-led government has cut down a significant chunk of the news channels which crushed the freedom of expression because massive downsizing was observed in almost all the news channels and other related media organizations.

\section{Conclusion and Discussion}

Keeping in view the patterns of qualitative data, five categories and five main themes were developed to discuss and analyze the data. Based on the main themes, data analysis concluded the study with the findings that news freedom of expression is not a privilege but a social responsibility associated with the free press in any civilized society across the globe. Media organizations in Pakistan should first become socially responsible only then freedom of expression can be observed inside and outside the organizations. The study concluded that Pakistani media organizations are owned by the businessmen therefore no hard and fast rule for ethical journalism is adopted or practiced by the traditional media organization rather vested interests of the owners of the traditional organizations are protected. The stud further concluded news policy, editorial policy and program policy of the private news organization is devised in accordance with the policy of the owner, who enjoys his friendly relations with political masters, armed personnel, powerful bureaucrats and leaders of the religious parties therefore the owner himself has covered under the veil of 'social pressure'. The study shared that downsizing in media organizations has put the future of media and communication discipline at stake if this issue is not addressed at appropriate forums including government, All Pakistan Newspapers Society (APNS), Council of Pakistan Newspaper Editors (CPNE), Pakistan Electronic Media Regulatory Authority (PEMRA), Ministry of Information and Broadcasting Pakistan, Press Information Department (PID), Directorate General of Public Relations (DGPR) and other sectors. The study recommended that social media is taking lead and has become a dominant media therefore all the news organizations should also transform themselves in according with the emerging trends in global media market. The study further 
concluded that we need to develop a culture of respect to human life in Pakistan only then we can observe honest, ethical and unbiased news policy in private traditional media organizations. According to the conclusion, the concept of job satisfaction cannot be developed among the journalists until or unless a comprehensive policy by the government is enforced compelling all the owners of the traditional media organizations to abide by for wider interest of the state, economic and psychological wellbeing of the journalistic community.

\section{References}

Acemoglu, D., \& Robinson, J. A. (2020). The narrow corridor: States, societies, and the fate of liberty: Penguin Books.

Akhavan-Majid, R., \& Wolf, G. (1991). American mass media and the myth of libertarianism: Toward an "elite power group"; theory. Critical Studies in Media Communication, 8(2), 139-151.

Baker, C. E. (1977). Scope of the First Amendment freedom of speech. Ucla L. Rev., 25, 964.

Bell, J. (2018). A presidential mouthpiece: How Fox News reflect Donald Trump and his government's stance on North Korea within their online discourse.

Bennett, C. J., \& Raab, C. D. (2017). The governance of privacy: Policy instruments in global perspective: Routledge.

Billig, M. (2002). Talking of the royal family: Routledge.

Boaz, D. (2010). Libertarianism: Simon and Schuster.

Bollinger, L. C. (1994). Images of a free press: University of Chicago Press.

Booth, L., Aivazian, V., Demirguc-Kunt, A., \& Maksimovic, V. (2001). Capital structures in developing countries. The journal of finance, 56(1), 87-130.

Boserup, R. A., Woertz, E., Hassan, H., Nagyné Rózsa, E., \& Zaccara, L. (2019). Restoration, transformation and adaptation: Authoritarianism after 2011 in Egypt, Saudi Arabia and Iran: Istituto Affari Internazionali.

Christians, C. G., Glasser, T., McQuail, D., Nordenstreng, K., \& White, R. A. (2010). Normative theories of the media: Journalism in democratic societies: University of Illinois Press.

Davies, N. (2011). Flat earth news: An award-winning reporter exposes falsehood, distortion and propaganda in the global media: Random House.

Downie Jr, L., \& Kaiser, R. G. (2007). The news about the news: American journalism in peril: Vintage.

Dyson, M. E., \& Jagerman, D. L. (2000). I may not get there with you: The true Martin Luther King, Jr (Vol. 233): Simon and Schuster.

Frum, D., \& Perle, R. N. (2004). An end to evil: How to win the war on terror: Random House Digital, Inc.

Graber, D. A., \& Dunaway, J. (2017). Mass media and American politics: Cq Press.

Grant, W. (1989). Pressure groups, politics and democracy in Britain: Springer.

Gunther, R., \& Diamond, L. (2003). Species of political parties: A new typology. Party politics, 9(2), 167-199.

Hali, S. M. (2010). LIAQUAT ALI KHAN-AN UNHERALDED FOUNDING FATHER OF PAKISTAN. the Denial of Justice Liaquat Ali Khan-An Unheralded Sultan M Hali 132 Founding Father of Pakistan 1971-Lessons Et Cetera Iqbal Ahmad Khan 170 Essays, 132.

Hartley, J. (2019). Communication, cultural and media studies: The key concepts: Routledge.

Herman, E. S., \& Chomsky, N. (2010). Manufacturing consent: The political economy of the mass media: Random House.

Heydarian, R. J. (2020). The Great Distraction: The Near East and North Korea The Indo-Pacific: Trump, China, and the New Struggle for Global Mastery (pp. 47-91): Springer.

Ho, K. (2007). Structural violence as a human rights violation: University of Essex Essex.

Humphreys, P. J. (1996). Mass media and media policy in Western Europe (Vol. 2): Manchester University Press.

Kalia, R. (2012). Jinnah's Pakistan Pakistan: From the rhetoric of democracy to the rise of militancy (pp. 14-58): Routledge India.

Kapoor, C. (2016). The Emergency: A Personal History: Penguin UK. 
Klausen, J. (2005). The Islamic challenge: politics and religion in Western Europe: Oxford University Press.

Ogundiya, I. S. (2010). Democracy and good governance: Nigerias dilemma. African journal of political science and international relations, 4(6), 201-208.

Pickering, I. (2017). Writing for News Media: The Storyteller's Craft: Routledge.

Plunkett, J. (2003). Queen Victoria: first media monarch: Oxford University Press on Demand.

Price, M. E. (2002). Media and sovereignty: The global information revolution and its challenge to state power: MIT press.

Rabban, D. M. (1985). The Ahistorical Historian: Leonard Levy on Freedom of Expression in Early American History: JSTOR.

Roberts, A. (2001). Structural pluralism and the right to information. The University of Toronto Law Journal, 51(3), 243-271.

Robinson, W. I., \& Robinson, W. I. (2004). A theory of global capitalism: Production, class, and state in a transnational world: JHU Press.

Sakr, N. (2013). Transformations in Egyptian journalism: Bloomsbury Publishing.

Shahbaz, S. (2020). Caught in the Cross-Fire of Religion, Culture, and Politics: Women's Sexual and Reproductive Health and Rights in Pakistan Gender Mainstreaming in Politics, Administration and Development in South Asia (pp. 231-254): Springer.

Smith, J. A. (1990). Printers and press freedom: The ideology of early American journalism: Oxford University Press.

Steel, J. (2013). Journalism and free speech: Routledge.

Steiniger, S., \& Hunter, A. J. (2013). The 2012 free and open source GIS software map-A guide to facilitate research, development, and adoption. Computers, environment and urban systems, 39, 136-150.

Sultana, T. (2012). Montesquieu's doctrine of separation of powers: A case study of Pakistan. Journal of European Studies, 28(2).

Suwannathat-Pian, K. (2013). Kings, country and constitutions: Thailand's political development 19322000: Routledge.

Von Bogdandy, A., Kottmann, M., Antpohler, C., \& Dickschen, J. (2012). Reverse Solange-protecting the Essence of fundamental rights against EU Member States. Common Market L. Rev., 49, 489.

Woertz, E. (2019). Aramco geht an die Börse: Saudi-Arabiens Diversifikationsproblem. GIGA Focus Nahost(05). 